\title{
FORMS OF PHYSICAL ACTIVITY OF BIAŁA PODLASKA PRESCHOOL CHILDREN
}

\author{
PAULINA GRADUS ${ }^{1}$, EWA BENZA ${ }^{1}$, OLGA RYBAK ${ }^{1}$, PAWEŁ KRZYSZTON ${ }^{1}$, \\ PAULINA BATORZYŃSKA ${ }^{1}$, MAGDALENA PLANDOWSKA ${ }^{2}$, WIESŁAW LECH KURPETA ${ }^{2}$ \\ Józef Piłsudski University of Physical Education in Warsaw, Faculty of Physical Education and Sport \\ in Biała Podlaska, Student Scientific Club of Theory and Methodology of Physical Education ${ }^{1}$, \\ Department of Theory and Methodology of Physical Education ${ }^{2}$
}

\author{
Mailing address: Magdalena Plandowska, Faculty of Physical Education and Sport, \\ Department of Theory and Methodology of Physical Education, 2 Akademicka Street, \\ 21-500 Biała Podlaska, tel.: +48 83 3428745, fax: +48 83 3428800, \\ e-mail: magdalena.plandowska@awf-bp.edu.pl
}

\begin{abstract}
Introduction. Physical activity is fundamental to children's all-round development in the first six years of their life. It is particularly significant in preschool age, when the need for movement is predominant. Psychomotor development, conditioned by children's innate abilities and their own activity, depends upon the influence of external surroundings as well as parental upbringing and preschool education. The aim of the study was to obtain data regarding physical activity (both structured and unstructured) of children during their stay in a kindergarten. Material and methods. The study was conducted in five state kindergartens situated in four main housing estates of Biała Podlaska. It included 11 groups of older preschool children. It was a diagnostic study. A diagnostic poll method employed in the study included interviews with teachers, lesson observations (during one day) and document analyses (programmes and class registers). Results. During their stay in a kindergarten children take part in physical activities for 1.5 hours a day. During this period they participate in obligatory forms of physical activity such as morning gymnastics, movement plays, outdoor activities and gymnastic exercises. Furthermore, optional movement activities are organised in kindergartens (different forms in different kindergartens). Such extra classes enable children to be physically active for over two more hours per week. Conclusions. In terms of caring about health and motor development of children, not all elements of preschool education programmes are fully realised. Training sessions, workshops and lectures showing diverse forms of physical activity for children ought to be organised for preschool teachers.
\end{abstract}

Key words: preschool age, need for movement, physical activity, movement activities

\section{Introduction}

Physical activity is fundamental to children's all-round development in the first six years of their life. Physical education is closely connected with mental, moral and aesthetic education as well as education that teaches respect for work.

Considering a wide range of motor skills and their excellent performance, the $5^{\text {th }}$ and the $6^{\text {th }}$ year of a child's life is known as 'the golden period of motor abilities' or 'the first motor height' [1, $2,3]$. In this period a child is capable of acquiring several motor skills simultaneously as well as putting together the moves they learnt into routines (a 4-year-old child can throw and catch a ball easily and learn a running routine with kicking a ball, whereas 6-year-olds can usually catch a ball and immediately throw it at the target, and some of them are able to perform a more difficult routine of a run-up throw). Such results are achieved owing to three things, i.e. considerable need for movement, great sensitivity to stimuli and sufficient levels of motor, mental and social maturity [1,2].

Versatile physical activity acts as the basic developmental stimulus and a natural form of activity. It is the most characteristic feature of early ontogenetic phases. The need for movement reveals a child's curiosity of the world and it is a constantly growing source of knowledge of the surroundings and body capabil- ities. It is also a foundation for creating one's own values [1]. The process of human cognition does not occur through passive acts of contemplation or by analysing sensations. It occurs when one struggles with the environment in an active manner. One can get to know an object through interacting with it and modifying it [4]. As Piaget noted, "cognition does not stem from sensory perceptions or observations but from activities in their entirety" [5]. In the course of activity children collect perceptions and observations, gain experience, expand ideas and notions and form their memory, attention and thinking [6]. The significance of cognition through experiencing (at an enactive level, a process of learning and getting to know reality is based on acting i.e. touching, moving, motor coordination and experience, with visual perceptions supporting it) was stressed by Bruner [7] and Kephart [8]. Intellectual development consists in acquiring three forms of representation, where enactive representation is the basis for creating other (iconic and symbolic) representations [7]. According to Kephart, any kind of behaviour is conditioned by muscular and motor reactions, while physical activity is the primary source of knowledge concerning reality. Behaviour develops from basic sensory and motor abilities and the so-called higher forms of behaviour depend on them [8].

The awareness of mutual influence of mental processes and motor development as well as deep cognition of a child's physi- 
cal development and its mechanisms help to understand failures when working with children. Therefore, contemporary pedagogy finds physical activity extremely significant in terms of education and formation as it is considered to be one of the most important factors that equally stimulates body and mind. For this reason, when educational processes are directed at the development of a child's motor sphere, it is crucial to be conscious of possible consequences regarding the development of other spheres. It is particularly essential in preschool age when movement, being one of the predominant needs, leads to great mobility of a child. Children themselves are not aware of this need and they do not discuss it with adults. Movement is the need that cannot be suppressed, postponed or eliminated completely. A constant need for physical activity, compared to 'the hunger for movement', manifests itself through energy-filled, unstructured and spontaneous activity that disturbs adults or is just dangerous [9].

Kucera attempted to define children's physical activity needs in optimal conditions by using the method of a hidden camera [10]. His findings revealed that preschool children need approximately 6 hours of activity - boys or 5 hours and 15 minutes - girls (with boys demonstrating a greater need for movement). Kucera defined intensive activity as all the actions which made children's heart rate increase by $50 \%$ compared to the heart rate at rest (telemetric registration of heart rate).

According to hygienic norms of basic elements of children and youth's daily routine, it is assumed that 3 hours of activity daily is a minimum amount $[11,12]$ and it should include at least 60 minutes of moderate-to-vigorous physical activity $[13,14,15]$. Moreover, a child should spend 2-3 hours in the open and green area $[11,16]$.

Psychomotor development, conditioned by children's innate abilities and their own activity, depends upon the influence of external surroundings as well as parental upbringing and preschool education [17]. Gruszczyk-Kolczyńska and Zielińska point to the occurrence of unfavourable tendencies in family upbringing and preschool education (providing insufficient opportunities for children to give vent to their energy and spend time outdoors). Such tendencies are the source of neglect in the field of physical education (e.g. not meeting children's need for physical activity and for staying outdoors) $[18,19]$. The findings of Plandowska [20] revealed that physical activities organised in preschool (gymnastics, outdoor and indoor games and plays, rhythmics classes) constituted basic forms of physical activity among preschool children. For over half of the older preschool children such activities are the only way to fulfil their need for physical activity and staying outdoors.

It is not only parents but also teachers who have to make sure that children's need for movement is fulfilled. Teachers ought to support parents in developing their children. Taking care of children's fitness and physical activity is one of the most crucial tasks of preschool teachers [21]. In terms of developing physical fitness, preschool curriculum aims at strengthening children's bodies, improving their overall fitness and helping them to acquire sports and recreational skills as well as developing their creativity. It includes morning gymnastics, corrective gymnastics (exercises and plays that shape a proper body posture), rhythmics classes, perceptual and social participation activities. It also includes the following types of exercises: jumps, throws, balance exercises, on all fours, exercises with elements of rolling, carrying and climbing as well as games and plays in snow, on ice and in water [22, 23]. Physical activity performed by children on their own should take up almost half of their overall activity time in a kindergarten. Performing morning gymnastics, playing movement games and other physical exercises should not take more than 1.5-2 hours a day and they ought to be distributed in a rational way. Outdoor physical activity should take as much time as indoor activities [24]. According to curricular guidelines, it is recommended that a fifth of the time children spend in preschool should be devoted to staying in a garden, park or on a pitch, where movement games and plays as well as sports classes ought to be organised for them (Ministry of Education ordinance) [25]. This regulation optimises the functioning of kindergartens in terms of caring about physical development and health education of children.

The aim of the study was to obtain the data regarding physical activity (structured and unstructured) of children during their stay in a kindergarten. The following research questions were asked:

1. What forms of physical activity (structured and unstructured) do children participate in when they stay in a kindergarten?

2. How much time do teachers devote to these forms?

\section{Material and methods}

The study was conducted in five state kindergartens situated in four main housing estates of Biała Podlaska. The kindergartens under investigation are large facilities of considerable usable area. Three kindergartens are located in two-storey buildings. The institutions have suitable conditions for conducting physical education classes. The rooms are spacious and bright and equipped with didactic aids and sports accessories, e.g. rubber balls, small sacks, ringo, hoops, pucks, pins, sashes, ropes or blankets. Moreover, one kindergarten has very good conditions as in the basement there is a small gymnastic hall with an adjoining storeroom for sports and recreational equipment. All the kindergartens have large outdoor terraces as well as playgrounds with indispensable equipment (swings, slides, sandpits and other outdoor devices). One of the kindergartens has a pool with balls set up in the corridor which is generally available as a playground for children.

In the year 2013/2014 the kindergartens were attended by 464 older preschool children (74 seven-year-olds, 192 six-yearolds and 198 five-year-olds) in 14 groups. The study included 11 preschool groups (one group of 4-5-year-olds, three groups of 5year-olds, five groups of 5-6-year-olds and two groups of 6-yearolds).

The groups are supervised by qualified female staff. Most of the teachers are graduates of M.A. studies and have pedagogical qualifications in the field of preschool education. One teacher graduated from Teacher Training College.

The examined kindergartens use one of the following preschool education programmes: Elżbieta Tokarska, Jolanta Kopała - 'Before I become a pupil' [27]; Małgorzata Kwaśniewska, Wiesława Żaba-Żabińska - 'Our kindergarten. Preschool education programme enhancing the development of children's activity' [28]; Barbara Bilewicz-Kuźnia, Teresa Parczewska 'Towards a child' [29]. The programmes include, inter alia, such areas as health education and the development of children's physical fitness [27], physical and health activity [28] as well as corporal and kinaesthetic abilities [29]. In these areas the programmes provide information on the content and forms that ought to be realised during physical activity classes in particular age groups. According to the authors of the aforementioned programmes, they should be realised through organising movement games and plays (plays aimed at improving body posture, perceptual and social participation activities, on-all-fours games, activities with elements of running, jumping, rolling, throwing and catching as well as balance activities and plays with storytelling and singing), outdoor activities (in a garden, in a park or on a pitch) in different seasons (in snow or water) and gymnastic exercises with the use of standard methods as well as through using unconventional aids (plastic bottles, rubber bands, newspapers, strings or boxes) in plays and games, 
organising plays with elements of competition, combining physical activity with rest, developing body movement expression, organising rhythm and dance exercises, creating opportunities for children to perform movement plays spontaneously, and the like.

A diagnostic poll method was employed in the study. It included interviews with teachers, lesson observations in a kindergarten (during one day) and document analyses (programmes and class registers) [26]. The interviews with teachers (categorised as overt) concerned the forms of physical activity taken up by children in a kindergarten, ways of dealing with patterns of behaviour that show children's need for physical activity and types of sporting events organised by a kindergarten for children (and parents). Observations (covert) provided feedback on forms of physical activity performed by children during they stay in a kindergarten and on their patterns of behaviour that showed their need for physical activity. Documents (class registers, preschool education programmes) helped to analyse the content and forms of movement realised during physical activity classes in particular age groups.

The study was carried out in the winter and spring season.

The SPSS 21 programme was used for the analysis. The hierarchical cluster analysis method was applied with the technique of calculating a distance matrix (Euclidean distance). A dendrogram was created on the basis of the matrix.

\section{Results}

During their stay in a kindergarten children take part in physical activities for 1.5 hours a day. During this period they participate in obligatory forms of physical activity such as morning gymnastics, movement plays, outdoor activities and gymnastic exercises. Furthermore, optional movement activities are organised in kindergartens (different forms in different kindergartens). Such extra classes enable children to be physically active for over two more hours per week (fig. 1 and 2).

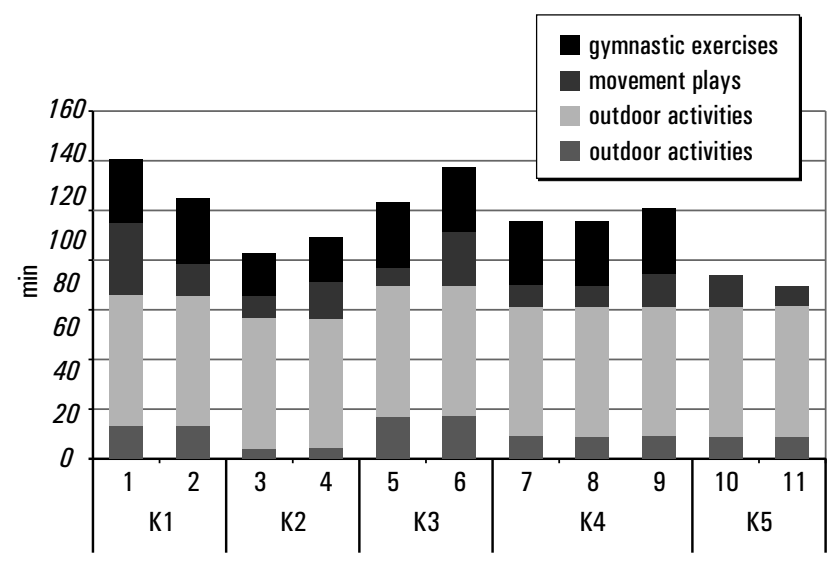

$\mathrm{x}$ - kindergarten group number; $(\mathrm{Kx})$ - kindergarten number.

Figure 1. Obligatory forms of physical activity of children in a kindergarten

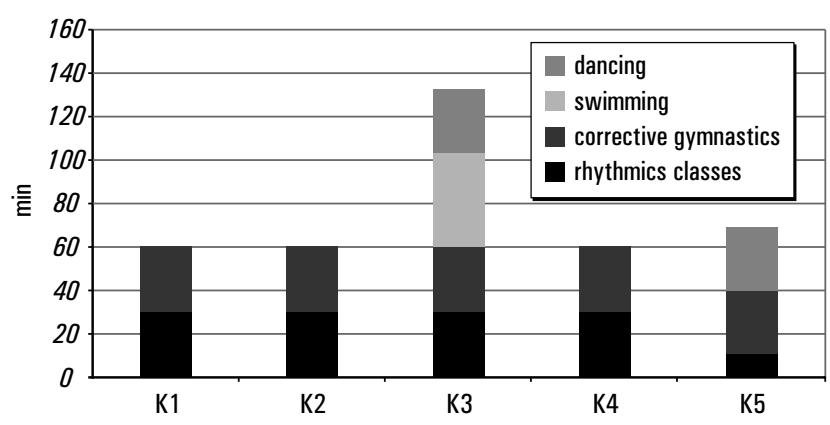

$\mathrm{Kx}$ - kindergarten number.

Figure 2. Optional forms of physical activity of children in a kindergarten

Morning gymnastics takes place every day before breakfast and, depending on the institution, it lasts between 5 and 20 minutes. In one kindergarten gymnastics takes place once a week only and it lasts 15 minutes.

Another form of physical activity that children participate in on a daily basis is movement plays. These include structured plays organised by a teacher that take place during the breaks between didactic classes as well as plays spontaneously taken up by children in the time of free plays. Structured plays consist most commonly of running plays as well as singing plays, e.g. 'Dyrygent' ('Conductor'), 'Bocian i żaby' ('Stork and frogs'), 'Jeśli jesteś wesoły' ('If you are cheerful'), 'Misiu, misiu' ('Bear, bear'), 'Wiosna' ('Spring'), 'Zakochany bałwan' ('Snowman in love'), etc. There are three or four 3-minute movement plays per day. In total, structured plays take from 10 to 30 minutes daily. Other types of plays such as perceptual and social participation plays, on-all-fours games, plays with elements of jumping, throwing and kicking or balance plays are not organised by the kindergartens under examination. When it comes to free plays (daily schedules include 4 such periods of approximately 30 minutes each), boys usually perform running activities (running with objects resembling planes), whereas girls engage in manipulation plays. It is difficult to define how much time children spend performing movement plays as part of free plays since such activities are quickly suppressed by teachers. Moreover, children do not always know how to spend their free time. It is noticeable through such patterns of behaviour as trying to attract attention by picking on or disturbing other children during plays. In such situations teachers ought to react by taking the initiative and organising structured movement plays.

Time spent outdoors is usually devoted to walking (around kindergarten premises or to a nearby park) and playing in a garden. The observations revealed that children spend about 60 minutes outdoors and this time depends on the weather. In the authors' opinion, weather conditions were favourable on the days of the observation. According to teachers, unfavourable conditions for such forms of physical activity include rain, strong wind and temperatures below $-5^{\circ} \mathrm{C}$. The study showed that there is a need for conducting various forms of structured movement plays outdoors.

Gymnastic exercises aimed at all-round development are also done in kindergartens. In ten groups they take place twice or three times a week and last approximately 20-30 minutes each. In one group gymnastic exercises are done for 20 minutes every day.

Furthermore, kindergartens offer optional forms of physical activity that take place once a week in the afternoon and last 30 minutes. Such activities usually require extra payment and they include corrective gymnastics, rhythmics classes, swimming or dancing. In all the institutions corrective classes are 
Table 1. The matrix of distances between particular kindergarten groups regarding the total time devoted to various forms of physical activity of children during their stay in a kindergarten

\begin{tabular}{|c|c|c|c|c|c|c|c|c|c|c|c|}
\hline \multirow{2}{*}{ Kindergarten groups } & \multicolumn{9}{|c|}{ Kindergarten groups } \\
\cline { 2 - 13 } & 1 & 2 & $\mathbf{3}$ & $\mathbf{4}$ & $\mathbf{5}$ & $\mathbf{6}$ & $\mathbf{7}$ & $\mathbf{8}$ & $\mathbf{9}$ & $\mathbf{1 0}$ & $\mathbf{1 1}$ \\
\hline $\mathbf{1}$ & .000 & .317 & .465 & .372 & $\mathbf{1 . 0 0 2}$ & .880 & .186 & .425 & .354 & .867 & .898 \\
\hline $\mathbf{2}$ & .317 & .000 & .251 & .240 & .884 & .860 & .465 & .155 & .143 & .798 & .805 \\
\hline $\mathbf{3}$ & .465 & .251 & .000 & .118 & .897 & .897 & .569 & .204 & .227 & .705 & .705 \\
\hline $\mathbf{4}$ & .372 & .240 & .118 & .000 & .920 & .882 & .459 & .230 & .207 & .701 & .712 \\
\hline $\mathbf{5}$ & $\mathbf{1 . 0 0 2}$ & .884 & .897 & .920 & .000 & .298 & $\mathbf{1 . 0 8 8 ^ { 2 }}$ & .885 & .902 & .945 & .938 \\
\hline $\mathbf{6}$ & .880 & .860 & .897 & .882 & .298 & .000 & .934 & .888 & .877 & .924 & .938 \\
\hline $\mathbf{7}$ & .186 & .465 & .569 & .459 & $\mathbf{1 . 0 8 8 ^ { 2 }}$ & .934 & .000 & .534 & .451 & .912 & .949 \\
\hline $\mathbf{8}$ & .425 & $.155^{1}$ & $.204^{1}$ & $.230^{1}$ & .885 & .888 & .534 & .000 & .085 & .785 & .783 \\
\hline $\mathbf{9}$ & .354 & $.143^{1}$ & $.227^{1}$ & $.207^{1}$ & .902 & .877 & .451 & .085 & .000 & .782 & .787 \\
\hline $\mathbf{1 0}$ & .867 & .798 & .705 & .701 & .945 & .924 & .912 & .785 & .782 & .000 & .069 \\
\hline $\mathbf{1 1}$ & .898 & .805 & .705 & .712 & .938 & .938 & .949 & .783 & .787 & .069 & .000 \\
\hline
\end{tabular}

Groups that make up the biggest cluster of kindergarten groups similar in the total time devoted to various forms of physical activity of children during their stay in a kindergarten.

${ }^{2}$ Groups with the biggest differences in the total time devoted to various forms of physical activity of children during their stay in a kindergarten.

attended by children with faulty body postures. One kindergarten allows all children to participate in corrective gymnastics if parents give their written consent. Only four kindergartens offer rhythmics classes. In one of them such classes are conducted by a preschool teacher five times a week for 10 minutes each (rhythmics is a part of daily schedule, classes are obligatory), while the remaining three institutions offer payable activities supervised by an outside person that take place once a week for 30 minutes. Dance classes are held in two kindergartens and last 30 minutes. Only one institution organises swimming classes (45 minutes, once a week).

Based on the data regarding the analysis of cluster dissimilarity between the objects (tab. 1 and fig. 3), it can be stated that the biggest cluster of kindergarten groups (assuming the distance no greater than 5) that are similar in the total time devoted to physical activity of children during their stay in a kindergarten is formed by group 2 (Kindergarten 1), groups 3 and 4 (Kindergarten 2) as well as groups 8 and 9 (Kindergarten 4) (the cluster was formed in the third linkage; the distance in which these elements were linked forming a new single cluster is 2.53) (fig. 3). The largest differences in the time devoted to various forms of physical activity of children during their stay in a kindergarten were noted between group 1 (Kindergarten 1 ) and group 5 (Kindergarten 3 ) as well as group 5 (Kindergarten 3 ) and group 7 (Kindergarten 4) (tab. 1). Compared to group 5, groups 1 and 7 do not organise optional activities such as swimming or dancing but they devote much more time to movement plays.

Kindergartens also organise diverse events that mainly include drama and focus on plays and performances staged in front of parents. Such events rarely concern physical activity. A vast majority of sporting events for preschool children are initiated and organised by the students from the Faculty of Physical Education and Sport in Biała Podlaska. The events include 'Olympic Games for preschool children', 'Mum, dad, play with me' and 'Sports day'. They are held once a year in the spring-summer season.

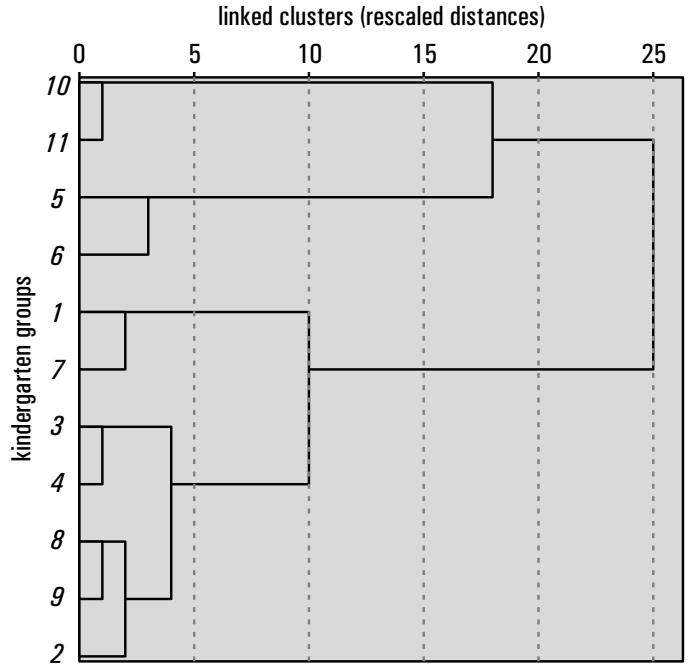

Figure 3. A dendrogram illustrating the total time devoted to various forms of physical activity of children in particular kindergarten groups

\section{Discussion}

The research results reveal that the kindergartens in Biała Podlaska have suitable conditions for conducting interesting and intensive physical education classes for children during their stay in a kindergarten. The findings of the study carried out by Rokicka-Hebel (in Gdańsk) [30] as well as Górniak and Łobacz (in Biała Podlaska) [31] also show that the kindergartens they investigated had good conditions for accomplishing health education objectives.

The study revealed that during their stay in a kindergarten children take part in physical activities that are not varied. It is borne out by the patterns of behaviour that children manifest like fidgeting, picking on others or running around the room. It shows that the children's need for physical activity is not fulfilled. The findings are in line with the results obtained by other authors. According to Rokicka-Hebel [30], usually the 
same games and plays are performed without taking into consideration perceptual and social participation activities, running plays, balance activities, on-all-fours games, activities with elements of throwing, aiming, rolling, climbing or jumping. In her opinion, when children stay outdoors, various movement plays should also be organised for them. They ought to include plays that require more space (running, jumping, throwing) as well as activities with elements of climbing different objects and plays with elements of balance on a higher platform. Kamińska and Woynarowska [32] observed that when staying outdoors some children do not take up any form of activity on their own initiative. It also shows there is a need to organise physical activities for children staying outdoors.

\section{Conclusions}

1. During their stay in a kindergarten children take part in obligatory forms of physical activity such as morning gymnastics, movement plays, staying outdoors and gymnastic exercises. Moreover, optional movement activities like corrective gymnastics, swimming, rhythmics classes or dancing are organised in kindergartens.

2. Teachers devote $\mathbf{1 . 5}$ hours a day to realising obligatory forms of physical activity for children. Furthermore, owing to their participation in optional movement activities children can be physically active for over two more hours per week.

3. In terms of caring about health and motor development of children, not all elements of preschool education programmes are fully realised, which is not conducive to forming positive attitudes of children towards physical culture.

4. Training sessions, workshops and lectures showing diverse forms of physical activity for children ought to be organised for preschool teachers.

\section{Literature}

1. Przewęda R. (1973). Somatic and motor development. Warszawa: PZWS. [in Polish]

2. Przewęda R. (1980). About motor changes in human life. Warszawa: PTNKF. [in Polish]

3. Wolański N. (Ed.) (1980). Biomedical foundations of development and education. Warszawa: PZWL. [in Polish]

4. Gilewicz Z. (1964). Theory of physical education. Warszawa: SiT. [in Polish]

5. Piaget J. (1977). Psychology and epistemology. Warszawa: PWN. [in Polish]

6. Szuman S. (1955). The role of activity in a child's mental development. Warszawa: PAN. [in Polish]

7. Bruner J. (1978). Apart from provided information. Warszawa: PWN. [in Polish]

8. Kephart N.C. (1970). A child with learning difficulties. Warszawa: PWN. [in Polish]

9. Bergier B., Kubińska E. (1998). Craving for physical activity. Edukacja i Dialog 10, 40-41. [in Polish]

10. Kucera M. (1983). Quality assessment of children's need for physical activity. Wychowanie Fizyczne i Higiena Szkolna 8, 323-325. [in Polish]

11. Kosicki B. (1980). Selected topics and exercises in the field of hygiene. Warszawa-Poznań: PWN. [in Polish]

12. Łobożewicz T., Wolańska T. (1994). Recreation and tourism in a family. Warszawa: Estrella. [in Polish]

13. Vale S., Trost S., Riuz J., Rego C., Moreira P., Mota J. (2013). Physical activity guidelines and preschooler's obesity status. International Journal of Obesity 37(10), 352-1355. DOI: 10.1038/ijo.2013.109.

14. Strong W.B., Malina R.M., Blimkie C.J., Daniels S.R., Dishman R.K., Gutin B. (2005). Evidence based physical activity for school-age youth. Journal of Paediatrics 146, 732-737.

15. World Health Organization. (2010). Global recommendation of physical activity for health. Geneva: WHO Press.

16. Bartkowiak Z. (1980). Biomedical foundations of development and education. Part II. Warszawa: WSiP. [in Polish]

17. Zebrowska M. (1986). Theories of mental development. In M. Żebrowska (Ed.), Developmental psychology of children and youth (pp. 123-190). Volume I. Warszawa: PWN. [in Polish]

18. Gruszczyk-Kolczyńska E., Zielińska E. (2007). The programme of supporting the development, upbringing and education of older preschool children (4- and 5-year-olds). Warszawa: Nowa Era. [in Polish]

19. Gruszczyk-Kolczyńska E., Zielińska E. (2012). Two- and three-year-olds in preschool and at home. Kraków: Centrum Edukacyjne Bliżej Przedszkola. [in Polish]

20. Plandowska M. (2014). An outline of the issue of the need for physical activity among preschool children - as exemplified by Biala Podlaska area. Polish Journal of Sport and Tourism 21(1), 25-35. DOI: 10.2478/pjst-2014-0004.

21. Chabros E., Charzewska E. (2011). Physical activity of preschool children. In J. Charzewska (Ed.), Recommendations for caterers in the field of proper nutrition of children in kindergartens (pp. 53-62). Warszawa: Instytut Żywienia i Żywności. [in Polish]

22. Klim-Klimaszewska A. (2012). Preschool pedagogy. New core curriculum. Warszawa: ERICA [in Polish]

23. Turlińska-Kępys J. (1994). Physical education in a kindergarten. Lider 2, 4-6. [in Polish]

24. Wilczkowski E. (2012). Physical education of preschool children. Piotrków Trybunalski: NWP. [in Polish]

25. Ministry of National Education. (2008). National curriculum of preschool education for preschools, preschool groups in primary schools and other forms of preschool education. Attachment no 1 to the resolution of the Minister of National Education from 23 December 2008 (Official Journal of Laws from 15 January 2009 No 4 , item 17). [in Polish].

26. Pilch T. (1998). The rules of pedagogical research. Warszawa: Wydawnictwo Akademickie Żak. [in Polish]

27. Tokarska E., Kopała J. (2009). Before I become a pupil. Preschool education programme. Warszawa: Wydawnictwo Edukacja Polska. [in Polish]

28. Kwaśniewska M., Żaba-Żabińska W. (2009). Our kindergarten. Preschool education programme enhancing the development of children's activity. Kielce: Wydawnictwo MAC. [in Polish]

29. Bilewicz-Kuźnia B., Parczewska T. (2009). Towards a child. Preschool education programme. Lublin: Nowa Era. [in Polish]

30. Rokicka-Hebel M. (2005). The role of a kindergarten in educating a child for physical activity. In T. Lisicki, B. Wilk, A. Walentukiewicz (Eds), Pro-health lifestyle: social conditioning (pp. 119-126). Gdańsk: AWFiS. [in Polish]

31. Górniak K., Łobacz R. (1996). About a preschool child's need for physical activity. In K. Górniak, S. Arasymowicz (Eds), Corrective exercises in preschool. Methodological Conference 28-29.05.1996. [Biała Podlaska] (pp. 24-29). Warszawa: PTNKF. [in Polish]

32. Kamińska K., Woynarowska B. (1986). Physical activity of 4year-olds and 6-year-olds during their stay in a kindergarten. Wychowanie Fizyczne i Sport 3, 59-66. [in Polish]

Submitted: : July 4, 2014

Accepted: September 23, 2014 